\title{
Cooperative Learning Strategies in Citizenship Education Subject in Elementary Schools During the Pandemic Covid-19
}

\author{
Elinna Dyah Finanti ${ }^{1, *}$, Marzuki $^{2}$ \\ Yogyakarta State University, Jl. Colombo Yogyakarta No.1, Sleman, Daerah Istimewa Yogyakarta 55281 Indonesia \\ 1elinnadyah.2019@student.uny.ac.id*; ${ }^{2}$ marzuki@uny.ac.id \\ * corresponding author
}

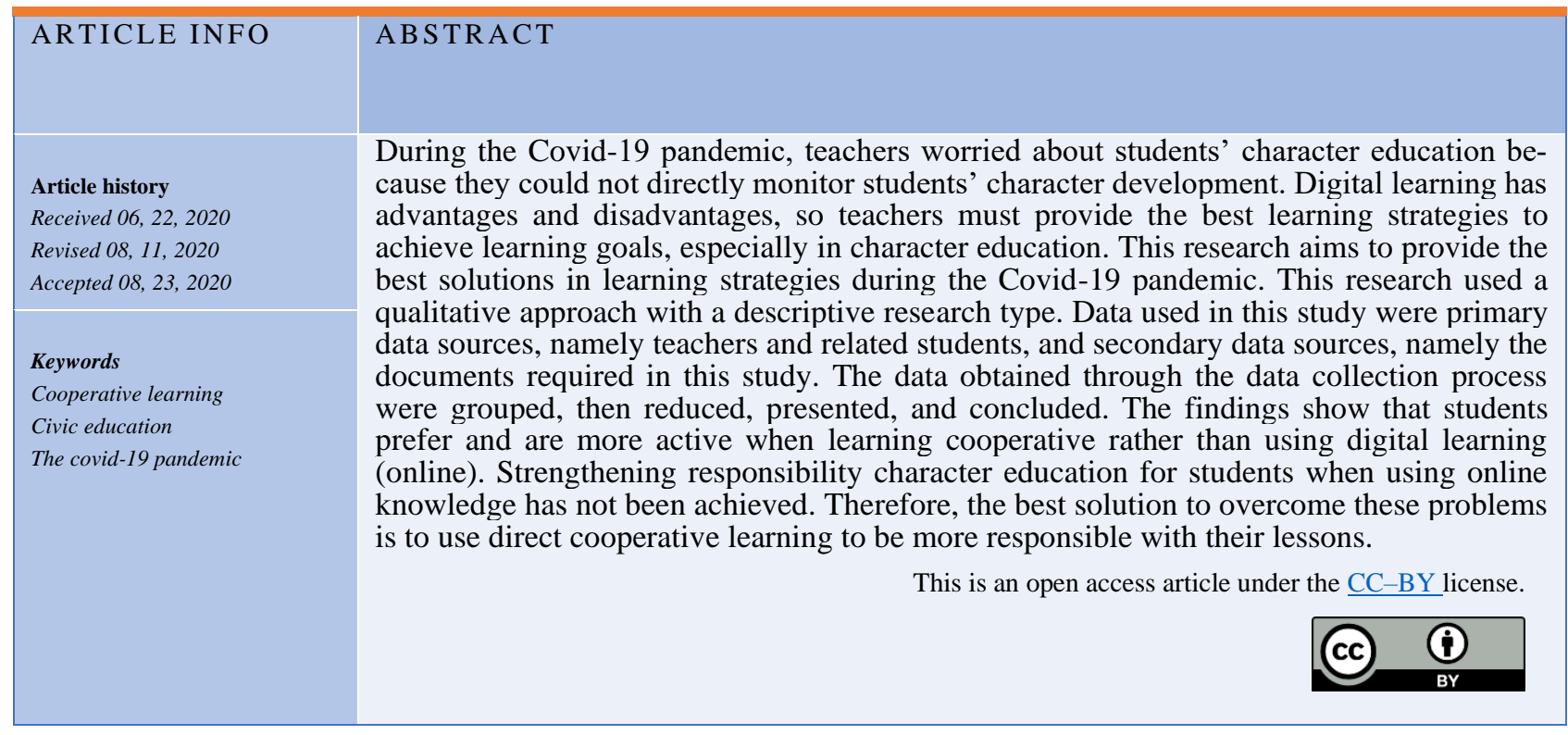

\section{Introduction}

Every nation must be severe in realizing the ideals of the country. The purposes of the Indonesian people are written in the fourth paragraph of the Preamble to the Republic of Indonesia Law of 1945, namely, to protect the entire Indonesian nation and all Indonesian bloodshed and promote public welfare and educate the nation's life and participate in implementing world order. One of the efforts to realize these ideals is the development of human resources. Zamroni, (2016) states that social resource development includes three main dimensions: mastery of knowledge, character, and skills. The ability of character affects two other sizes. Data from the Badan Narkotika Nasional, (2020) stated that the national prevalence rate in 2019, the number of drug users aged 15-65 years in Indonesia, reached 3,419,188 people. This shows that the character of the Indonesian nation is not yet fully characterized by Pancasila. Meanwhile, data from the Badan Pusat Statistik, (2020a) states that the number of criminal acts according to the regional police in 2018 was 294,281 cases. Cases like this can be caused by several things, including a lack of character education, unfavorable environmental influences, economic needs, and so on.
Character education is crucial in life. A smart but immoral country will destroy the country. For example, a person who serves as a Regent or Governor is undoubtedly intelligent. Still, if these officials commit disgraceful acts or violate laws such as corruption, these officials do not have Pancasila's character. Data from the Badan Pusat Statistik, (2020b) reports that the anti-corruption behavior index is 3.84. This figure has increased compared to the previous year, namely 3.70 , which indicates that the public is increasingly anti-corruption behavior. However, corruption cases still exist and have become a culture of both small and sizeable nominal corruption. According to Koesoemo, (2017), the investigation process carried out by the KPK during 2015 consisted of 27 cases, while investigative activities were carried out in 106 patients. If the KPK only bears eradicating corruption, it will be a challenging task and will never be completed. Therefore, a system that can change this culture of corruption is needed. Through education, the most effective strategy is anti-corruption education, which is implemented in an integrated manner, from primary to tertiary education (Zuber, 2018). 
Kay, (2008) and Elmunsyah, (2014) identifies five essential abilities in life, namely: (a) work ethic, (b) ability to collaborate, (c) communication skills, (d) social responsibility, and (e) critical thinking and problem-solving. In this case, most of the abilities needed in the $21^{\text {st }}$ century are abilities in the aspect of the character. The success of a 21 st century nation depends on the success of education in developing students' character. Zamroni, (2016) stated that the New Zealand Department of Education carried out curriculum reform by emphasizing that students must master five necessary abilities, which stress character development, namely: (a) critical thinking and problem-solving skills, (b) the ability to use language, symbols, and text, (c) the ability to control oneself (able to motivate oneself, have a "can-do" attitude "a can-do attitude," be able to plan can-the future), (d) the ability to relate and work together (the ability to listen, the ability to recognize differences of opinion, the ability to negotiate, the ability to think together) and, (e) the ability to participate and contribute to the welfare of the community (the ability to participate in various activities, the ability to contribute, the ability to create opportunities). These necessary abilities are developed and applied to each subject.

Indonesia includes character education in particular subjects, namely Pancasila and Citizenship Education. Each approach implemented has advantages and disadvantages. In the case of New Zealand, Kerr, (1999) argues that several countries are using a mixed approach to civic education. The character will provide direction and considerations on how to achieve goals. The character will provide guidance and concerns on how to achieve goals. Characters can grow and develop naturally, depending on environmental conditions. If the character that grows and develops naturally is not necessarily good because everyone does not always have a good environment, the character that grows and develops is also greatly influenced by the environment.

One of the obstacles to improving the quality of education in Indonesia is a moral crisis that is increasingly rampant. Both the government, education providers such as the minister of education, school principals, and teachers must make developments every day to increase the quality of education in Indonesia. This character does not grow by itself in everyone but needs social engineering, which is planned, implemented, and as carefully as possible. The implementation process is very long; it will even last all time, especially through education, so that the concept of character education will be born specifically.

The state of education in Indonesia still requires development in the quality of education. This can be seen based on a survey conducted by the Program for
International Student Assessment (PISA) in 2018, that for reading competency scores, Indonesia is ranked 73 out of 76 countries, for Mathematics scores, is ranked 73 out of 77 countries, for science scores ranked 75 out of 77 countries (O.E.C.D., 2018). This value has tended to be stagnant in the last 10-15 years. Based on the National Human Development Reports (2018), the Human Development Index in the education sector in Indonesia is ranked 111 out of 189 countries, while in 2015, Indonesia was ranked 110 out of 187 countries (U.N.D.P., 2018).

Good characters that have grown and developed in students will not automatically increase student achievement. Zamroni, (2016) proposed strategies to achieve high achievement for each student, including (a) teacher's mind setting, changes in the way the teacher sees himself towards students (b) investment, where every teacher identifies, explores, practices try and reflects, in new ways of education. Teachers always try to improve what has been and will be done in learning, (c) school culture and policies, especially the principal and his team must understand, prepare, and implement work programs and infrastructure appropriately, and (d) educational transformation in the form of collaboration in togetherness. School life in planning, implementing, and evaluating based on the spirit and spirit of togetherness, collaboration, and cooperation provides opportunities for teachers to enjoy and celebrate the learning process together.

Character education is education for practical life, not knowledge about the character. Dempster, (2020) explains that character education aims to produce people who can show ethical principles in life, both for themselves and others. Character building should start as a child because that age is a golden age that makes a child have a good or bad character. A person's character can also be influenced by the family environment, community environment, school environment, and from within a person. The family environment is the first environment for a child to interact, so that the family is the most important environment in shaping character. Character education is also the responsibility of educational institutions as representatives of the government, parents, and society in a harmonious collaboration that avoids inequality. Therefore, it is necessary to empower the right tips, such as real-life practice, simulation, roleplaying, modeling, or modeling, and problemsolving (Suparno, 2016). The Covid-19 pandemic is currently endemic in all countries in the world. To minimize this, the government states that students must learn from home using online-based learning (Affandi et al., 2020). Sibilana, (2020) revealed that in the field of education, the development of information and communication technology has changed the way people learn and seek information. On the 
other hand, it can change the way people interpret the information they get. However, until the change of the new academic year, the Covid-19 pandemic has not ended, so that the Ministry of Education and Culture has issued guidelines for the formal implementation of home learning (Kementrian Pendidikan dan Kebudayaan, 2020).

Learning from home, often referred to as onlinebased learning (digital learning), uses a tool or network as an intermediary. Digital learning is a way to obtain digital teaching materials online or offline learning activities via a wired or wireless network (Hockly, 2012). This digital learning-based learning has advantages and disadvantages. The advantages of digital learning include students being able to learn flexibly, casually, and can be done anywhere and anytime. According to Lin et al., (2017), the effects of digital learning are: (a) digital learning has a better positive effect on learning motivation than traditional teaching, (b) digital learning shows a better positive effect on learning outcomes than traditional learning, (c) learning motivation shows a significant positive effect on learning effects on learning outcomes, (d) learning motivation appears to have a very positive effect on learning acquisition in learning outcomes. The disadvantages of digital learning-based learning include: some students do not have qualified equipment, such as smartphones, computers, Wi-Fi networks, or data packages. The country of Indonesia is still not ready for digital learning because there are still students in the interior, so there is no network. Learning through digital learning also raises concerns about understanding the material that students will accept. Understanding the material, but the application of character is also very worrying because the teacher cannot know or control students' character directly.

Based on the advantages and disadvantages obtained from digital learning-based learning, teachers must provide the best learning strategies to achieve learning goals, especially in character education. Direct supervision of strengthening children's character education is reduced so that learning during the Covid-19 pandemic does not run as usual. The character of responsibility possessed by students must be better monitored. Responsibility for learning, doing, and collecting assignments. The learning strategies carried out by the teacher are sometimes inappropriate when applied. There are various kinds of learning strategies that teachers can apply, one of which is the cooperative learning strategy. Cooperative learning strategies can be referred to as group learning. The cooperative learning strategy is the best solution to overcome the problems described because learning groups of students are more active in thinking, the more interacting and communicating. The broader the students' insights will be the teacher's assign- ment will also be carried out to strengthen the character of responsibility as a student. The novelty of this study compared to other studies that have been conducted is that this study was conducted during the Covid-19 pandemic. Therefore, in this study, the authors are interested in discussing more deeply cooperative learning strategies in civic education subjects in primary schools during the Covid-19 pandemic.

\section{Method}

This research used a qualitative approach with a descriptive research type. This research took place at SDN Bagorejo 04, Bagorejo Village, Gumukmas District, Jember Regency. Sources of data used in this study are primary data sources, namely teachers and related students, and secondary data sources, namely the documents required. Researchers used three kinds of data collection techniques, namely, observation, interviews, and documentation. The data that has been obtained through the data collection process are grouped and then analyzed. The data analysis used in this study is an analysis using the model from (Miles \& Huberman, 1992), which includes three steps, namely data reduction, data display (data presentation), and data conclusion (data verification). In checking the validity of the data, this study uses a triangulation technique to compare the research findings with various sources, methods, or theories.

\section{Results and Discussion}

The results of this study revealed that cooperative learning strategies are more efficient than digital (online) learning. Based on the results of interviews from researchers to homeroom teachers from class I to class VI and interviews with students from grades I to grade VI, it is suggested that face-to-face (offline) learning is preferable and more effective than digital (online) learning. Students explain that digital learning makes students lazy to do assignments so that the assignments given by the teacher are ignored. Therefore, the teacher provides the best solution in solving this problem, namely by learning in groups or cooperatively. In this case, there is a slight difference in cooperative learning strategies. This cooperative learning strategy is carried out in schools with heterogeneous group division. In that case, this cooperative learning strategy is not carried out at school but at the home of one of the students from each class. This can be done because there are only 35 students from SDN Bagorejo 04 as follows.

In class I, the number of male students is six students, the number of female students is two students, the total number of students in class I is eight students. In Class II, the number of male students is 
three students, the number of female students is one student. The total number of students in class II is four students. In Class III, the number of male students is four students, the number of female students is two students, the total number of students in class III is six students. In class IV, the number of male students is five students; the number of female students is two students; the total number of students in grade IV is seven students. In Class V, the number of male students is two students, the number of female students is two students, the total number of students in class V is four students. In Class VI, the number of male students is four students, the number of female students is two students, the total number of students in class VI is six students. The total number of male students is 24 students, while the total number of all female students is 11 students, so all students in grades I-VI are 35 students.

Given the Covid-19 virus pandemic, the government has prohibited groups or congregations. The school principal and teacher at SDN Bagorejo 04 provided this solution with many considerations, namely: (1) students are not responsible for their duties when using digital (online) learning; (2) the number of students is not too large so that it can minimize the risk of spreading the Covid-19 virus; (3) teachers and students continue to implement health protocols in accordance with recommendations from the government; (4) the principal and teachers gave the opinion that there were no newcomers from outside the region so that it would minimize the risk of spreading the Covid-19 virus; (5) teachers can directly monitor the progress of students; (6) this group learning is not done every day, but the teacher divides the time by teaching online and offline.

The schedule of group study for each class varies depending on the agreement between the teacher and students. The study schedule for class I to class VI students is as follows. Class I, Monday, Tuesday, Wednesday, and Friday conduct cooperative learning (offline), while on Thursday and Saturday, cooperative learning is closed. Class II, Monday, Wednesday, and Friday conduct cooperative learning (offline), while on Tuesday, Thursday, and Saturday, conduct online learning. Class III, Monday, and Wednesday conduct cooperative learning (offline), while on Tuesday, Thursday, Friday, and Saturday conduct online learning. Class IV, Monday, Tuesday, and Wednesday conduct cooperative learning (offline), while on Thursday, Friday, and Saturday do online learning. Class V, Monday, Tuesday, Wednesday, Thursday, and Friday, conducts cooperative learning (offline), while on Saturdays, it does online learning. Class VI, Monday, Tuesday, Wednesday, and Thursday conduct cooperative learning (offline), while on Friday and Saturday do online learning.
Class I does not use digital (online) learning because teaching class I requires tenacity and patience and can only be taught offline. This can be understood considering that the material for class I is basic material such as learning to read, write, and count so that the teacher must teach directly to listen, monitor, and justify the student learning process. Because of the material, in elementary school-age children, teachers must instill good characters for students, and characters can only be taught directly or contextually to record and apply these characters in their daily lives. Therefore, teachers must teach in person or offline for this age of primary school children.

The same thing was done by the homeroom teacher of class $\mathrm{V}$, the homeroom teacher and the teacher who taught class V already knew the character of each student, so that group-based offline learning was very effective to be applied to class V. The homeroom teacher of class $\mathrm{V}$ explained that class students $\mathrm{V}$ is very difficult to regulate so that tasks delivered through digital (online) learning are not done, children's concentration levels decrease, children's enthusiasm for learning also decreases because they are not used to learning online. Students do not feel they have a duty or learning responsibility because the teacher does not directly monitor them, so students do not care about the assignments given by the teacher. Therefore, the teacher provides the best solution, namely through face-to-face (offline) learning with cooperative learning strategies, which are expected to minimize the risk from the background of the problem.

\section{A. Cooperative Learning Strategy}

Cooperative learning is a learning strategy by forming study groups. According to Siegel, (2015), cooperative learning involves groups of students working on completing a task together. The same thing was stated by Artzt \& Newman, (1990); cooperative learning is an approach that involves a small group of students working together as a team to solve problems, complete tasks, or achieve common goals. Cooperative learning at SDN Bagorejo 04 is a group learning consisting of 4-8 students. The number of students in SDN Bagorejo 04 class I-VI is 35 students. Each class only formed 1 study group because of the small number of students. Following the theory of cooperative learning, a group can consist of 4-5 members so that learning can be effective and comprehensive. Teachers can do groups limited to three to five members (Johnson \& Johnson, 1999).

In this case, group members must realize that they are part of a team and that all group members will share the group's success or failure. Therefore, to achieve group goals, students need to talk to each other about problems and help each other. The teacher at SDN Bagorejo 04 does not allow his students to 
study independently even though a study group has been formed. Teachers continue to monitor, correct wrong, provide motivation and advice to students. Therefore, learning becomes fun, and students can understand the material smoothly.

In this case, students become more active and interact more often with their friends to provide students with extensive knowledge through peer interaction. This is also in accordance with what Igel \& Urquhort, (2012) stated, social and constructivist learning theory states that humans acquire and expand knowledge through interactions with one another. There are different characteristics of students; some are embarrassed to ask the teacher questions, some are quiet so that if they do not understand the material, they stay quiet, and so on. This cooperative learning is very effective in overcoming the character of these students. Students can ask their friends without being embarrassed, and sometimes the language of their peers is easier to understand than the teacher. Therefore, cooperative learning is very solution in dealing with these problems.

Based on research conducted by Igel \& Urquhort, (2012), social learning experiences, which are often called group or cooperative learning in the classroom, can have a positive impact on adolescents. Artzt \& Newman, (1990), group members are motivated to prepare their work, do tasks with a set time, and can achieve, because these behaviors lead to group approval and success. Researchers also observed that with the cooperative learning carried out by each teacher at SDN Bagorejo 04, students were more active in interacting with others. Students are not ashamed to ask the teacher because the teacher blends into the group to monitor, unlike in school, the teacher sits in front of the class. Cooperative learning at SDN Bagorejo 04 is slightly different from the usual cooperative learning concept; what distinguishes here is the place of learning. Due to the Covid-19 virus pandemic, the government prohibited face-to-face learning (offline), so schools were closed but replaced with digital (online) learning.

The place of study is in one of the students' homes, not at school because if it is at school, it will be a gathering place for grade I to grade VI students. However, here the teacher chooses a place to study in one of the students' homes, which is the most strategic location. The lesson hours in cooperative learning are also not long, starting at 08.00-10.00 WIB. These class hours are the same for grades I-IV; after learning is over, the teacher returns to school to be absent or daily meetings by implementing health protocols as recommended by the government.

Research conducted by Dean et al., (2012) explains that well-designed cooperative instruction has a consistently positive effect. Not only positive, ac- cording to Willis, (2007), neuroscience shows that cooperative learning is good for the brain. Cooperative learning can make students more active in thinking; the more interacting and communicating, the more knowledge students have so that cooperative learning is good for the brain. The same thing was stated by Elmore \& Zenus, (1992); the number of studies on the results and processes associated with cooperative learning shows that cooperative learning can effectively improve academic achievement and social skill development. According to Siegel, (2015), there are three principles in implementing cooperative learning strategies, as follows.

1) Teach group processing and interpersonal skills.

On this principle, the teacher can create groups with a small number of members, such as 4 or 5 members. Teachers must have skills in time management; effective use of time can provide concise statements to reinforce the material at the end of the lesson.

2) Establish cooperative goal structures within groups.

In this principle, each group must work together to achieve the goals that have been set. The teacher can distribute resources throughout the group so that all members must contribute to completing their respective assignments so that students can achieve the goals set.

Based on the results and discussion of this research, it can be understood that to minimize the lack of digital (online) learning during the Covid-19 pandemic, teachers can form cooperative learning groups for each class. Of course, this is done by implementing health protocols following government recommendations, such as wearing masks, not in groups with many people, and so on. The number of students at SDN Bagorejo 04 is relatively small because al-most every class of students does not have ten students, so the risk of contracting the Covid-19 virus is not too big. This group completing their respective assignments so that students can achieve the goals set.

\section{B. Provide mechanisms for individual ac- countability.}

On this principle, teachers should use an assessment that asks all members to be re-sponsible for all material. Each student must be responsible individually for studying the material; groups effectively achieve achievement. According to Frey, Frey et al., (2009), to be successful with cooperative learning, students usually need instruction in small group skills. The same thing was also expressed by Johnson et al., (1994), that the implementation of teacher cooperative learning is influenced by previous knowledge and experience and the current teaching con- 
text. Furthermore, Dean et al., (2012) added that interpersonal skills include skills needed to work well with others, such as active listening, providing constructive criticism, and respecting other people's perspectives. Based on these theories, it can be understood that teachers must possess many skills and concepts for this cooperative learning to run optimally.

According to the researchers' point of view, the teacher at SDN Bagorejo 04 has understood the principles and skills in implementing this cooperative learning. This can be seen from the better student development, from the aspects of knowledge, attitudes, and skills. Researchers also observed that the teacher also provided reinforcement material at the end of the lesson. The teacher also corrects, monitors, and provides suggestions during learning.

\section{Conclusion}

Based on the results and discussion of this research, it can be understood that teachers can form cooperative learning groups for each class to minimize the lack of digital (online) learning during the Covid-19 pandemic. Of course, this is done by implementing health protocols following government recommendations, such as wearing masks, not in groups with many people, and so on. The number of students at SDN Bagorejo 04 is relatively small because almost every class of students does not have ten students, so the risk of contracting the Covid-19 virus is not too big. This group study is not done every day; each class has its policies and schedules for scheduling online or offline learning. Therefore, there is a balance in this learning system; the teacher can directly monitor students' development from the aspects of knowledge, attitudes, and character, especially the character of responsibility through this group learning.

\section{References}

Affandi, A., Sarwani, A. S., Erlangga, H., Siagian, A. O., Purwanto, A., Effendy, A. A., \& Wahyitno, C. D. M. (2020). Optimization of MSMEs Empowerment in Facing Competition in the Global Market during the COVID-19 Pandemic Time. Systematic Reviews in Pharmacy, 11(11), 15061515.

Artzt, A. F., \& Newman, C. M. (1990). Implementing the standards: Cooperative learning. The Mathematics Teacher, 83(6), 448-452.

Badan Narkotika Nasional. (2020). Survei prevalensi penyalahgunaan narkoba tahun 2019. BNN.

Badan Pusat Statistik. (2020a). Indeks perilaku anti korupsi (IPAK) menurut dimensi 2018-2020.

Badan Pusat Statistik. (2020b). Jumlah tindak pidana menurut kepolisian daerah 2016-2018.
Dean, C. B., Hubbell, E. R., Pitler, H., \& Stone, B. J. (2012). Classroom instruction that works (2nd ed.). Association for Supervi-sion and Curriculum Develo.

Dempster, M. (2020). An exploration of character education as a tool of "moral repair" in the developing world.' Journal of Religious EducaTion, 68(July), 249-265. https://doi.org/10.1007/s40839-020-00107-5.

Elmore, R. F., \& Zenus, V. (1992). Enhancing social emotional development of middle school gifted students. Roeper Review, 16(3), 182-185. https://doi.org/10.1080/02783199409553569

Frey, N., Fisher, D., \& Everlove, S. (2009). Productive group work: How to engage students, build teamwork, and promote understandingAlexandria. Association for Supervision and Curriculum Development.

Hockly, N. (2012). Substitute or redefine? Modern English Teacher, 21(3), 40-42.

Igel, C., \& Urquhort, V. (2012). Generation Z, meet cooperative learning. Middle School Journal, 43(4), 16-21.

Johnson, D. W., \& Johnson, R. T. (1999). Learning together and alone (5th ed.). Al-lyn \& Bacon.

Johnson, D. W., Johnson, R. T., \& Holubec, E. J. (1994). The new circles of learning: Cooperation in the classroom and school. Association for Supervision and Curricu-lum Development.

Kay, K. (2008). Preparing every child for the 21 st century. President Partnership for 21st Century Skills APEC EdNet.

Kementrian Pendidikan dan Kebudayaan. (2020). Kemendikbud terbitkan pedoman penyelenggaraan belajar dari rumah (Nomor: 128/sipres/A6/V/2020). Kementerian Pendidikan Dan Kebudayaan Republik Indonesia.

Kerr, D. (1999). Citizenship education in the curricu-lum: An international review. NFER.

Koesoemo, C. R. T. (2017). Eksistensi komisi pemberantasan korupsi (KPK) dalam penanganan penyidikan dan penuntutan tindak pidana korupsi. Lex Crimen, 6(1), 62-70.

Lin, M. H., Chen, H. C., \& Liu, K. S. (2017). A study of the effects of digital learning on learning motivation and learning outcome. Eurasia: Journal of Mathematics Science and Technol-Ogy Education, 13(7), 3553-3564. https://doi.org/10.12973/eurasia.2017.00744a

Miles, B. M., \& Huberman, M. (1992). Analisis data kualitatif buku sumber tentang metode-metode baru. UIP.

O.E.C.D. (2018). Indonesia: Student performance (PISA, 2018).

Sibilana, A. R. (2020). Pendidikan Karakter Melalui Pembelajaran Berbasis Multiple Intelligences di Markaz Arabiyah Pare Kediri. Indonesian Journal of Islamic Education Studies (IJIES), 3(1), 48-62. 
Siegel, C. (2015). Implementing a research-based model of cooperative learning. The Journal of Educational Research, 98(6), 339-349.

Suparno, S. (2016). Pendidikan karakter. Yogyakarta State University.

U.N.D.P. (2018). Human development data (1990-2018).
Willis, J. (2007). Cooperative learning is a brain turn-on. Zamroni, Z. (2016). Pendidikan karakter. Yogyakarta State University.

Zuber, A. (2018). Strategi anti korupsi melalui pendekatan pendidikan formal dan KPK (komisi pemberantasan korupsi. Development and Social Change, I(2), 178-190. 